\title{
KETERAMPILAN GENERIK SAINS MELALUI MODEL PEMBELAJARAN PERUBAHAN KONSEPTUAL PADA MATERI ALAT-ALAT OPTIK PESERTA DIDIK
}

\section{GENERIC SCIENCE SKILL WITH CONCEPTUAL CHANGE LEARNING MODEL IN PHYSICS MATERIALS OPTICAL EQUIPMENT}

\author{
Sudianah sudianah $^{1 *}$, Muh. Makhrus², dan Muhammad Taufik ${ }^{2}$ \\ ${ }^{1}$ Program Studi Magister Pendidikan IPA, Universitas Mataram, Mataram, Indonesia \\ ${ }^{2}$ Program Studi Pendidikan Fisika FKIP, Universitas Mataram, Mataram, Indonesia \\ *Email: sudianahsanahsan@gmail.com
}

Diterima: 9 Oktober 2019. Disetujui: 18 Oktober 2019. Dipublikasikan: 9 Januari 2021

\begin{abstract}
Abstrak: Penelitian ini bertujuan untuk mendeskripsikan keterampilan generik sains peserta didik saat proses pembelajaran. Jenis penelitian ini adalah kuasi eksperimen dengan desain penelitian Non Equivalent Control Group design. Populasi penelitian adalah seluruh peserta didik kelas XI MIA SMAN 6 Mataram dengan teknik pengambilan sampel menggunakan purposive sampling. Keterampilan generik sains diperoleh pada saat proses pembelajaran dengan menggunakan LKPD. Keterampilan generik sains peserta didik pada saat pembelajaran, diperoleh bahwa kelas kontrol termasuk dalam kategori tinggi, sedangkan kelas eksperimen termasuk dalam kategori sangat tinggi. Berdasarkan hal tersebut, maka dapat dikatakan bahwa model pembelajaran perubahan konseptual baik digunakan untuk mengembangkan keterampilan generik sains pada materi alat-alat optik peserta didik SMAN 6 Mataram.
\end{abstract}

Kata Kunci: Perubahan Konseptual, Keterampilan Generik Sains

\begin{abstract}
The study aims to analyze the generic science skills of students during the learning process with conceptual change learning model. This type of research was a quasi-experimental research design NonEquivalent Control Group design. The population of this research were taken from all of the XI MIA grade students of SMAN 6 Mataram with sampling technique used purposive sampling. The generic science skills acquired during the learning process by using instruments equipped LKPD. The generic science skills of students during the learning obtained that control class in the high category, while the experimental group was included in the very high category. Analysis of research data shows that the conceptual change learning model is good to improve the generic science skills of optics of students of SMAN 6 Mataram.
\end{abstract}

Keywords: Conceptual change, generic science skills

\section{PENDAHULUAN}

Pembelajaran merupakan suatu proses belajar yang melibatkan guru, peserta didik, dan sumber belajar, sehingga terjadi perubahan perilaku menjadi lebih baik. Pembelajaran fisika pada hakikatnya memerlukan kreativitas, pemikiran kritis dan sikap ilmiah dalam memahami konsep maupun memecahkan permasalahan. Model pembelajaran yang ideal dibutuhkan agar tercapai tujuan pembelajaran fisika.

Model pembelajaran ideal yang dimaksud adalah model pembelajaran yang melibatkan peserta didik secara aktif dalam belajar. Peserta didik dituntut dapat mengembangkan dan membangun pengetahuan dalam diri mereka sendiri dengan peran aktifnya pada kegiatan pembelajaran di dalam kelas, sehingga dapat memahami konsep fisika dengan baik. Pembelajaran fisika dengan kurikulum 2013 yang sedang berlaku memiliki tiga aspek penilaian, yaitu pengetahuan, sikap, dan keterampilan yang dimiliki oleh peserta didik. Fakta di sekolah keterampilan peserta didik jarang diasah. Guru diharapkan mampu mengembangkan keterampilan peserta didik ketika proses pembelajaran berlangsung. Keterampilan peserta didik berbagai macam, salah satunya yaitu keterampilan generik sains.

Keterampilan generik sains merupakan keterampilan untuk peningkatan kualitas sumber daya manusia abad 21. Peserta didik yang memiliki kemahiran generik akan memiliki prospek pekerjaan yang baik. Keterampilan generik yang dilakukan dalam bidang sains disebut dengan keterampilan generik sains, keterampilan yang sangat berguna bagi peserta didik untuk memecahkan masalah fisika di lingkungan sekitarnya maupun saat proses pembelajaran berlangsung. Keterampilan generik dapat dikembangkan dalam kurikulum pendidikan dan pembelajaran sains.

Keterampilan yang dapat dilatih dalam pembelajaran sains khususnya fisika yaitu keterampilan generik sains. Pembelajaran fisika memerlukan suatu keterampilan dasar tertentu yang 
penting dan semestinya dimiliki siswa untuk dapat membangun pengetahuan [1]. Keterampilan generik merupakan keterampilan yang penting untuk dimiliki oleh siswa. Kusdiwelirawan [2] mengemukakan bahwa tujuan pengembangan keterampilan generik sains yaitu agar pengetahuan dan keterampilan yang diperoleh dari hasil belajar dalam proses belajar mengajar dapat diaplikasikan dalam kehidupan nyata dan menjawab tantangan zaman yang semakin cepat perkembangannya terutama dalam hal sains dan teknologi.

Keterampilan generik sains adalah salah satu keterampilan yang harus dicapai oleh peserta didik melalui penguasaan kompetensi. Kompetensi yang dicapai tergantung dari komponen isi atau materi pelajaran yang diterima oleh peserta didik [3].Penguatan pada konsep-konsep fisika dengan menggunakan model pembelajaran yang tepat pada peserta didik merupakan hal yang penting dalam pembelajaran untuk meningkatkan keterampilan generik sains dan hasil belajar fisika peserta didik.

Studi pendahuluan yang dilakukan melalui observasi dan wawancara dengan peserta didik dan guru mata pelajaran fisika kelas XI SMAN 6 Mataram, bahwa mata pelajaran fisika sering dianggap sebagai pelajaran yang sulit, terlalu banyak rumus, dan membosankan. Proses pembelajaran di kelas hanya diarahkan kepada kemampuan peserta didik untuk menghafal informasi tanpa dituntut memahami dan memaknai proses informasi yang diingatnya, sehingga pemahaman konsep peserta didik menjadi rendah. Pemahaman konsep fisika yang rendah mengakibatkan rendahnya hasil belajar peserta didik. Faktor yang menyebabkan hasil belajar fisika peserta didik rendah diantaranya adalah: (1) Pembelajaran fisika menerapkan metode diskusi untuk menyelesaikan soal-soal fisika yang bersifat hitungan, sehingga peserta didik beranggapan bahwa pelajaran fisika identik dengan Matematika, (2) Konsep awal peserta didik kurang diperhatikan, (3) Peserta didik memiliki kecenderungan menghafal rumus daripada memahami konsep. Fakta tersebut menimbulkan persepsi peserta didik bahwa fisika lebih banyak mempelajari rumusrumus, (4) Guru masih mendominasi dan menjadi pusat pembelajaran (teacher center) sehingga belum memberikan kesempatan bagi peserta didik untuk belajar secara mandiri melalui kegiatan penemuan dan proses berpikir.

Perbaikan dalam kegiatan pembelajaran perlu dilakukan agar keterampilan generik sains peserta didik dapat meningkat. Alternatif pemecahan masalahnya adalah dengan menggunakan model pembelajaran perubahan konseptual. Model pembelajaran perubahan konseptual adalah suatu model pembelajaran yang berlandaskan paham konstruktivisme, yang menyatakan bahwa setiap peserta didik membentuk pengetahuannya sendiri berdasarkan hasil interaksinya dengan dunia nyata, sehingga peserta didik memiliki prakonsepsi dan prakonsepsi tersebut berubah setelah menerima konsep baru dalam pembelajaran. Model pembelajaran ini berlandaskan paradigma kontruktivis yang membantu siswa untuk menjembatani kesenjangan antara pengetahuan tentang fenomena keseharian dan konsep-konsep yang benar secara ilmiah.

Model pembelajaran perubahan konseptual akan memberikan pemahaman konsep yang sesuai dengan penemuan para ahli disertai dengan contoh yang relevan dan aplikasinya dalam kehidupan sehari-hari. Kelas yang menggunakan model perubahan konseptual, peserta didiknya lebih terlibat dalam diskusi dibandingkan dengan peserta didik di kelas yang tidak menggunakan model perubahan konseptual [4]. Model perubahan konseptual mendorong peserta didik untuk lebih bertanggung jawab atas pembelajaran mereka dibandingkan dengan kelas tanpa model perubahan konseptual.

Model perubahan konseptual menyebabkan terjadinya proses kognitif antara konsepsi awal dengan konsep baru. Pengetahuan awal atau prakonsepsi yang dimiliki peserta didik umumnya berbeda dengan konsep ilmiah dan para ahli serta ada juga yang sudah sesuai dengan konsep ilmiah. Prakonsepsi peserta didik dengan konsep ilmiah yang berbeda disebut konsepsi yang salah. Guru dalam melaksanakan pembelajaran terlebih dahulu mengetahui konsep-konsep yang dimiliki oleh peserta didik karena pada dasarnya peserta didik memiliki konsep ataupun teori menurut dirinya.

Ardhana [5] menemukan bahwa kelompok siswa yang melakukan pembelajaran dengan model perubahan konseptual secara signifikan menunjukkan pencapaian remidiasi miskonsepsi, kemampuan berpikir kritis, dan hasil belajar lebih tinggi dibandingkan dengan kelompok siswa yang melakukan pembelajaran konvensional. Model pembelajaran perubahan konseptual yang dikombinasikan dengan keterampilan generik sains memungkinkan proses pembelajaran menjadi lebih efektif.

\section{METODE PENELITIAN}

Penelitian ini merupakan penelitian deskriptif kuantitatif karena kegiatan utama dalam penelitian ini yaitu mendeskripsikan keterampilan generik sains peserta didik. Desain penelitian ini yaitu Non Equivalent Control Group design. Proses pembelajaran menggunakan model pembelajaran perubahan konseptual pada kelas eksperimen dan pembelajaran konvensional pada kelas kontrol. Subjek penelitian ini adalah peserta didik kelas XI MIA di SMAN 6 Mataram tahun 
pelajaran 2018/2019. Kelas XI MIA 2 sebanyak 25 orang sebagai kelas eksperimen dan kelas XI MIA 1 sebanyak 22 orang sebagai kelas kontrol dengan teknik pengambilan sampel yaitu purposive sampling.

Instrumen yang digunakan dalam penelitian ini berupa lembar penilaian keterampilan generik sains fisika peserta didik berdasarkan indikator keterampilan generik sains yang digunakan. Instrumen penilaian ini berupa hasil diskusi peserta didik secara berkelompok berupa lembar kerja peserta didik (LKPD). Setiap pertemuan membahas masing-masing sub materi pokok alat-alat optik, yaitu pemantulan cahaya, pembiasan cahaya dan alat optik (3 kali pertemuan). Keterampilan generik sains dianalisis menggunakan statistik deskriptif.

\section{HASIL DAN PEMBAHASAN}

Penelitian ini bertujuan untuk mendeskripsikan keterampilan generik sains yang dialami peserta didik SMAN 6 Mataram pada materi Alat-alat optik pada saat proses pembelajaran berlangsung di setiap pertemuan. Hasil penelitian yang telah dilakukan menunjukkan bahwa keterampilan generik sains peserta didik pada kelas eksperimen lebih tinggi dari pada kelas kontrol, hal ini ditunjukkan dari nilai keterampilan generik sains pada saat proses pembelajaran menggunakan LKPD Nilai kelas kontrol lebih rendah dari pada kelas eksperimen karena pada kelas kontrol diterapkan pembelajaran kovensional sedangkan pada kelas eksperimen diterapkan model pembelajaran perubahan konseptual. Data keterampilan generik sains peserta didik pada kelas eksperimen dan kelas kontrol berdasarkan LKPD disajikan pada Tabel 1 berikut.

Tabel 1. Nilai Keterampilan Generik Sains pada Saat Proses Pembelajaran melalui LKPD

\begin{tabular}{|c|c|c|c|c|c|c|c|}
\hline \multirow{2}{*}{ Kelas } & \multirow{2}{*}{ Pertemuan } & \multicolumn{4}{|c|}{ KGS } & \multirow{2}{*}{ Rata-Rata } & \multirow{2}{*}{ Kategori } \\
\hline & & A & B & $\mathrm{C}$ & $\mathrm{D}$ & & \\
\hline \multirow[t]{3}{*}{ Kontrol } & 1 & 74 & 100 & 65 & 89 & 81 & $\mathrm{~T}$ \\
\hline & 2 & 56 & 94 & 74 & 94 & 79 & $\mathrm{~T}$ \\
\hline & 3 & 50 & 95 & 69 & 97 & 78 & $\mathrm{~T}$ \\
\hline \multirow[t]{3}{*}{ Eksperimen } & 1 & 82 & 100 & 95 & 100 & 94 & ST \\
\hline & 2 & 70 & 100 & 94 & 94 & 89 & ST \\
\hline & 3 & 64 & 100 & 100 & 87 & 88 & ST \\
\hline
\end{tabular}

Keterangan:

A: Pengamatan Langsung; B: Bahasa Simbolik; C: Pemodelan Matematika; dan D: Membangun Konsep.

Kriteria Penilaian:

Sangat Tinggi (A): apabila memperoleh nilai $86-100$

Tinggi (B) : apabila memperoleh nilai $75-85$

Sedang (C) : apabila memperoleh nilai $60-74$

Kurang (D) : apabila memperoleh nilai $<60$

Data keterampilan generik sains peserta didik pada kelas eksperimen dan kelas kontrol berdasarkan LKPD juga disajikan pada Gambar 1 berikut. Hasil analisis keterampilan generik sains dapat dilihat pula pada Gambar 1 berikut.

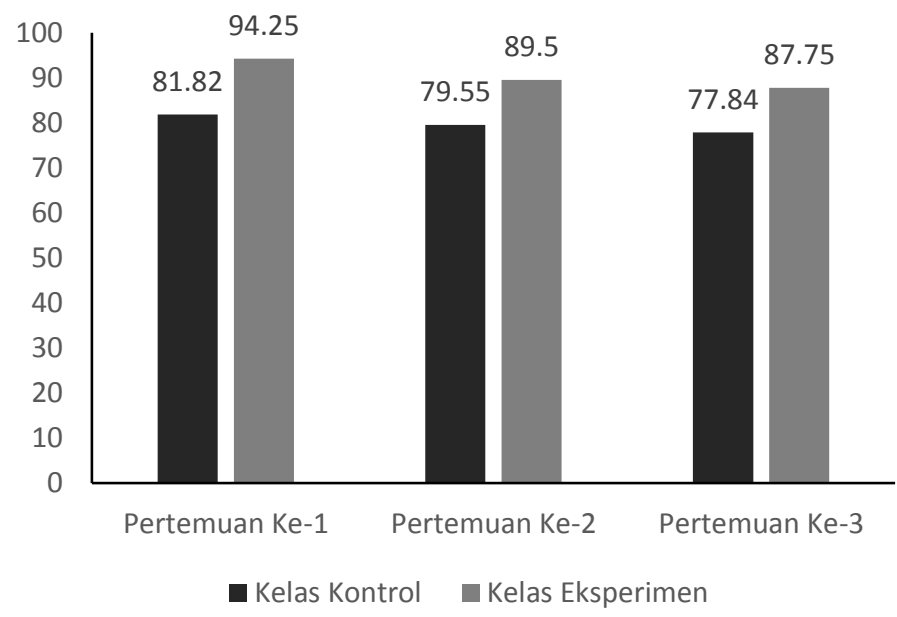

Gambar 1. Perbandingan Keterampilan Generik Sains pada Kelas Kontrol dan Kelas Eksperimen 
Penelitian ini menggunakan 4 indikator dari 9 indikator keterampilan generik sains yang dikemukakan oleh brotosiswoyo disebabkan karena indikator lain tidak bisa dimunculkan dalam pengembangan keterampilan generik sains disetiap pertemuan dalam LKPD.

Keterampilan generik sains di dalam proses pembelajaran di dalam kelas memberikan pengaruh pada hasil belajar fisika peserta didik. Model pembelajaran perubahan konseptual merupakan model yang tepat untuk mengajarkan peserta didik dalam melatih keterampilan generik sains khususnya pada materi alat-alat optik, materi ini tidak hanya disampaikan dalam bentuk soal latihan melainkan diperlukan permasalahanpermasalahan yang bersifat kontekstual untuk membangun keaktifan peserta didik selama proses pembelajaran di dalam kelas yang disajikan pada awal pembelajaran.

Proses pembelajaran yang berlangsung pada kelas eksperimen seperti halnya pembelajaran tanpa MPPK yang dimulai dari kegiatan awal sampai kegiatan akhir, namun MPPK menunjukkan adanya latihan untuk membentuk keterampilan generik sains dari LKPD yang diberikan kepada peserta didik. Kegiatan awal memberikan permasalahan yang bersifat konteksual atau yang sering diamati oleh peserta didik yang disebut fase orientasi. Penggunaan permasalahan yang bersifat kontekstual bertujuan untuk membuat peserta didik tertarik dalam proses pembelajaran selanjutnya. Peserta didik kemudian dituntut untuk menyampaikan pendapat yang mereka miliki tentang permasalahan yang telah diberikan yang masuk ke dalam fase elisitasi gagasan. Fase elisitasi gagasan ini sudah mulai mengajarkan peserta didik untuk berpikir benar atau tidak pendapat yang mereka kemukakan. Fase selanjutnya adalah restrukturasi gagasan, yaitu fase ketika guru akan menyampaikan materi secara umum yang berkaitan dengan pembelajaran dan mempersiapkan peserta didik melakukan percobaan dan diskusi kelompok, agar peserta didik dapat mengalami langsung peristiwa yang sesuai dengan materi yang dibahas. Fase aplikasi gagasan merupakan bagian dari model perubahan konseptual yang memberikan kesempatan kepada peserta didik untuk menerapkan konsep baru yang dimiliki melalui kegiatan diskusi melalui LKPD. Kegiatan akhir yang dilakukan adalah dengan mengajak peserta didik untuk meninjau kembali konsep-konsep yang dipelajari sebelumnya yang berada pada fase review perubahan konseptual.

Peneliti menemukan terjadi perubahan konsep yang dialami peserta didik pada saat proses pembelajaran. Pertemuan pertama pada materi pemantulan cahaya, sebagai penggalian konsepsi awal, peneliti menyajikan masalah dengan mendemonstrasikan hal yang berkaitan dengan pemantulan cahaya, yaitu menunjukkan laser yang dipantulkan terhadap cermin dan dibiaskan terhadap kaca, lalu peneliti mengajukan beberapa pertanyaan yaitu: (1) Apakah perbedaan antara kaca dan cermin, manakah yang dapat memantulkan cahaya? (2) Apakah yang anda ketahui tentang pemantulan? Peneliti menemukan kesalahan konsep yang dialami oleh beberapa peserta didik yakni peserta didik menganggap bahwa kaca dan cermin sama-sama dapat memantulkan cahaya. Konsep yang benar adalah cermin dapat memantulkan cahaya sedangkan kaca membiaskan cahaya yang masuk. Peserta didik juga menganggap bahwa besar sudut datang tidak sama dengan besar sudut pantul. Konsepsi yang dimiliki peserta didik tersebut masih mengalami kesalahan. Peserta didik kemudian diajak untuk melakukan percobaan agar menemukan sendiri konsep ilmiahnya. Setelah melakukan percobaan tentang hukum pemantulan, peserta didik menemukan sendiri konsep ilmiahnya bahwa sudut datang, garis normal, dan sudut pantul terletak pada suatu bidang datar dan besar sudut datang sama dengan sudut pantul. Kegiatan akhir pembelajaran, peneliti kembali menanyakan konsep yang sudah ditanyakan diawal dan memberikan penegasan konsep. Rangkaian pembelajaran yang diterapkan pada kelas eksperimen menunjukkan terdapat proses untuk melatih keterampilan generik sains sehingga peserta didik mampu menyelesaikan permasalahan dalam fisika khususnya materi alatalat optik, yang menyebabkan miskonsepsi pada peserta didik juga dapat teratasi dengan memberikan perhatian kepada konsepsi awal peserta didik.

Implementasi yang paling efektif dari model perubahan konseptual menurut Makhrus [6] yaitu dengan melibatkan aktivitas-aktivitas seperti pengajaran diagnostik, di mana pembelajaran didesain untuk mengungkapkan apa yang dipikirkan peserta didik sehubungan dengan permasalahan yang ada, mendiskusikan miskonsepsi-miskonsepsi mereka dengan penuh perhatian, dan memberikan situasi atau permasalahan yang membuat mereka berpikir untuk menyesuaikan atau mengupah pemikiran peserta didik. Aktivitas-aktivitas tersebut menyebabkan keterampilan generik sains peserta didik berkategori sangat tinggi pada peserta didik kelas eksperimen. Sudewa [7] menyatakan hal yang serupa yaitu melalui model MPPK peserta didik akan mengemukakan ide-ide mereka mengenai permasalahan-permasalahan melalui percobaan yang dilakukan sehingga miskonsepsi pada peserta didik dapat teratasi.

Keterampilan generik sains pada saat pembelajaran berdasarkan hasil diskusi perkelompok melalui praktikum dan penyelesaian permasalahan pada LKPD yang mencakup 
indikator keterampilan generik sains yang harus dicapai. Hasil yang didapatkan seperti yang terlihat pada Tabel 1 dan Gambar 1 bahwa keterampilan generik sains peserta didik kelas eksperimen termasuk dalam kategori sangat tinggi, sedangkan keterampilan generik sains peserta didik kelas kontrol termasuk dalam kategori tinggi dengan nilai rata-rata kelas eksperimen lebih tinggi dibandingkan dengan kelas kontrol. Peserta didik kelas eksperimen serius dan sangat memperhatikan guru ketika menjelaskan pelajaran dan ketika menjawab soal sebagian besar teliti dan rapi serta sangat diperhatikan satuan maupun proses dalam menjawab soal.

Keterampilan generik sains peserta didik kelas eksperimen termasuk dalam kategori sangat tinggi disebabkan karena peserta didik kelas eksperimen menjawab setiap persoalan yang dibuat berdasarkan indikator keterampilan generik sains secara detail dan lengkap serta penarikan kesimpulan sesuai dengan konsep dan hasil percobaan. Keterampilan generik sains peserta didik kelas kontrol termasuk dalam kategori tinggi disebabkan karena peserta didik kelas kontrol menjawab setiap persoalan dengan kurang lengkap serta penarikan kesimpulan masih ada yang kurang tepat. Fakta ini menunjukkan bahwa model pembelajaran perubahan konseptual mampu meningkatkan keterampilan generik sains peserta didik. Hasil yang diperoleh didukung oleh penelitian Sholehah [8] menyimpulkan bahwa model perubahan konseptual mampu mereduksi miskonsepsi peserta didik yang disebabkan oleh prakonsepsi peserta didik.

Besarnya nilai rata-rata keterampilan generik sains peserta didik tergantung dari tingkat kesukaran sub materi yang diajarkan. Keterampilan generik sains peserta didik kelas kontrol disetiap pertemuan memperoleh nilai rata-rata tertinggi pada indikator bahasa simbolik dan nilai rata-rata terendah pada indikator pengamatan langsung. Tingginya keterampilan generik sains peserta didik pada indikator bahasa simbolik disebabkan karena peserta didik dapat menulisakn simbol-simbol dengan tepat.

Keterampilan generik sains peserta didik kelas eksperimen memperoleh nilai rata-rata tertinggi pada indikator bahasa simbolik di setiap pertemuan dan memperoleh nilai rata-rata terendah pada indikator yang berbeda di setiap pertemuan. Pertemuan pertama pada sub materi pemantulan cahaya memperoleh nilai rata-rata tertinggi pada 2 indikator yakni bahasa simbolik karena peserta didik mampu menuliskan simbol-simbol dengan tepat, dan mendapatkan nilai rata-rata tertinggi pada indikator membangun konsep karena peserta didik mampu menambah konsep baru. Pertemuan kedua pada sub materi pembiasan cahaya juga mendapatkan nilai tertinggi pada indikator bahasa simbolik. Pertemuan ketiga pada sub materi alatalat optik, selain mendapatkan nilai rata-rata tertinggi pada indikator bahasa simbolik juga mendapatkan nilai tertinggi pada indikator pemodelan matematika karena peserta didik mampu mengungkapkan fenomena dalam bentuk rumusan dengan tepat. Keterampilan generik sains peserta didik memperoleh nilai rata-rata terendah setiap pertemuan pada indikator pengamatan langsung.

Keterampilan generik sains peserta didik kelas eksperimen dari pertemuan pertama sampai pertemuan terakhir menunjukkan nilai rata-rata yang selalu lebih tinggi dari daripada kelas kontrol. Hasil yang diperoleh menunjukkan bahwa keterampilan generik sains peserta didik pada kelas eksperimen lebih baik dibandingkan dengan keterampilan generik sains peserta didik kelas kontrol. Fakta ini menunjukkan bahwa model pembelajaran perubahan konseptual mampu meningkatkan keterampilan generik sains peserta didik. Keberhasilan model pembelajaran perubahan konseptual, sesuai dengan hasil penelitian Pebriyanti [9-10] yang menerapkan model pembelajaran perubahan konseptual menunjukkan bahwa model ini baik dalam mengatasi miskonsepsi fisika peserta didik.

\section{KESIMPULAN}

Berdasarkan hasil penelitian dan pembahasan dapat dibuat kesimpulan bahwa keterampilan generik sains peserta didik pada proses pembelajaran dikategorikan sangat tinggi untuk kelas eksperimen yang menggunakan model pembelajaran perubahan konseptual dan kategori tinggi untuk kelas kontol yang menggunakan pembelajaran konvensional berdasarkan LKPD pada setiap pertemuan, sehingga melalui model pembelajaran perubahan konseptual keterampilan generik sains peserta didik dapat meningkat terutama pada materi alat-alat optik.

\section{DAFTAR PUSTAKA}

[1] Sungkawaningtyas, E. (2018). Peningkatan Keterampilan Generik Sains dan Hasil Belajar IPA (Fisika) dengan Model Learning Cycle 5e Disertai Metode Eksperimen pada Siswa Kelas Ix-c SMP Negeri 1 Beji. Jurnal Pembelajaran Sains, 2(1), 13-18.

[2] Kusdiwelirawan, A., Hartini, T. I., \& Najihah, A. R. A. (2015). Perbandingan peningkatan keterampilan generik sains antara model inquiry based learning dengan model problem based learning. Omega: Jurnal Fisika dan Pendidikan Fisika, 1(2), 19-23.

[3] Agustinaningsih, W. (2013). Pengembangan instruksi praktikum berbasis keterampilan generik sains pada pembelajaran fisika materi teori kinetik gas kelas xi ipa sma negeri 8 
surakarta tahun ajaran 2012/2013 (Doctoral dissertation, UNS (Sebelas Maret University)).

[4] Sarar, M. M. A. (2014). The Effect Of Using Stepan's Model Of Conceptual Change on The Modification Of Altaernative Mathematical Concepts and The Ability Of Solving Mathematical Problems Of Ninth Grade Studnts in Jordan. European Scientific Journal, 10(22), 191-203.

[5] Ardhana, W., Purwanto, K. L., \& Santyasa, I. W. (2004). Implementasi pembelajaran inovatif untuk pemahaman dalam belajar fisika di SMU. Jurnal ilmu pendidikan, 11(2), 152168.

[6] Makhrus, M., Nur, M., \& Widodo, W. (2014). Model Perubahan Konseptual dengan Pendekatan Konflik Kognitif (MPKPKK). Jurnal Pijar MIPA, 9(1).

[7] Sudewa, P. H., Suma, K., \& Oktofa, D. (2017). Implementasi Model Pembelajaran Perubahan Konseptual untuk Meningkatkan Hasil Belajar
Fisika Siswa SMKN 3. Wahana Matematika dan Sains: Jurnal Matematika, Sains, dan Pembelajarannya, 8(1), 61-76.

[8] Sholehah, S. (2014). Reduksi Miskonsepsi Dengan Model Pembelajaran Conceptual Change pada Konsep Stoikiometri (Reduce Misconception with Conceptual Change Learning Model On Stoichiometry). UNESA Journal of Chemical Education, 3(3).

[9] Pebriyanti, D., Sahidu, H., \& Sutrio, S. (2017). Efektifitas Model Pembelajaran Perubahan Konseptual Untuk Mengatasi Miskonsepsi Fisika pada Siswa Kelas X Sman 1 Praya Barat Tahun Pelajaran 2012/2013. Jurnal Pendidikan Fisika dan Teknologi, 1(2), 92-96.

[10] Makhrus, M., Wahyudi, W., Taufik, M., \& Zuhdi, M. (2020). Validitas Perangkat Pembelajaran Berbasis CCM-CCA Pada Materi Dinamika Partikel. Jurnal Pijar Mipa, 15(1), 54-58. 